\title{
Genetic evidence of multiple paternity of broods in the intertidal crab Petrolisthes cinctipes
}

\author{
Robert J. Toonen ${ }^{1,2, *}$ \\ ${ }^{1}$ Center for Population Biology, Section of Evolution and Ecology, University of California, Davis, California 95616, USA \\ ${ }^{2}$ Present address: University of Hawaii at Manoa, School of Ocean and Earth Science and Technology, \\ The Hawaii Institute of Marine Biology, Coconut Island, PO Box 1346, Kaneohe, Hawaii 96744, USA
}

\begin{abstract}
Investigations of paternity among marine crustaceans are rare, but the few studies of brachyuran crabs that have been done to date suggest that most broods derive from single males. Here I use 2 hypervariable microsatellite loci to genotype a dozen brooded embryos from each of 10 gravid females of the porcelain crab Petrolisthes cinctipes (Anomura: Porcellanidae). Based on the number of non-maternal alleles detected among the offspring, at least 1 to 3 males must have fathered each of these broods, and most females were multiply mated. Using a Bayesian approach, I estimate the frequency of multiple mating to be roughly $92.5 \%$ in the Bodega Bay population, with a $95 \%$ confidence interval of 71 to $100 \%$ of females producing broods of multiple paternity.
\end{abstract}

KEY WORDS: Multiple mating $\cdot$ Paternity $\cdot$ Anomura $\cdot$ Microsatellite $\cdot$ Sperm competition $\cdot$ Mate choice

Resale or republication not permitted without written consent of the publisher

\section{INTRODUCTION}

Although male fitness generally increases in proportion to the number of successful matings garnered, the same is not typically true of females (reviewed by Hosken 1999, Birkhead 2000, Jennions \& Petrie 2000, Pizzari \& Birkhead 2002). Because females do not always gain an obvious fitness benefit from multiple matings, the reason why females mate with several males remains controversial (reviewed by Andersson 1994, Reynolds 1996). This is especially true of many insects and some crustaceans in which females are able to store enough viable sperm from a single copulation to last for much of their reproductive lifetime (reviewed by Hosken 1999).

Paternity in crabs has been infrequently investigated (e.g. Diesel 1989, 1991, Koga et al. 1993, Jensen et al. 1996, Urbani et al. 1998), but among the few species studied to date multiple paternity appears rare (reviewed by Urbani et al. 1998). The possible mechanisms for single paternity in the face of multiple matings by females fall into 2 primary categories: sperm stratification and sperm removal. Sperm removal may be accomplished via physical removal or displacement of ejaculate by subsequent males, but to date sperm removal has not been demonstrated in crabs. In cases of sperm stratification, last mate precedence in fertilization success is often observed (reviewed by Urbani et al. 1998). The mechanism of last male precedence appears to be that subsequent sperm displaces that of earlier matings toward the blind end of sperm storage organs, and away from the ducts which lead to the ovary (e.g. Diesel 1991, Urbani et al. 1998).

Unlike the brachyuran crabs, no internal sperm storage structures are known for anomuran crabs. In the Paguridae and Lithodidae, eggs appear to be fertilized externally after they are released, but before being attached to pleopodal setae for brooding (Nyblade 1987). In Paralithodes, sperm transfer is accomplished via modified fifth pereopods because there are no gonopods (Powell \& Nickerson 1965). Male Porcellanidae have similarly modified fifth pereopods, but also have a pair of gonopods, and it is not known how either function in copulation (G. Jensen pers. comm.). 
As part of a study to examine patterns of larval dispersal and population structure in this species, I developed highly polymorphic microsatellite markers (Toonen 2001) for the porcelain crab Petrolisthes cinctipes. In the course of testing these microsatellite loci, I undertook a study of patterns of inheritance of alleles at these loci, and discovered genetic evidence for multiple paternity of broods in $P$. cinctipes.

\section{MATERIALS AND METHODS}

Study organism. Petrolisthes cinctipes is a small suspension-feeding crab that uses modified maxillipeds to collect planktonic food items, especially detritus and diatoms (Wicksten 1973). P. cinctipes is restricted to a relatively narrow vertical zone of the rocky intertidal ( $\sim$ to $1.8 \mathrm{~m}$ above the mean low low water, MLLW) (Jensen \& Armstrong 1991). Individuals of both sexes and all size classes, from newly settled postlarvae $(\sim 1.5 \mathrm{~mm})$ to large adults (up to $20 \mathrm{~mm}$ carapace width), live together in large aggregations (up to 3933 ind. $\mathrm{m}^{-2}$ ) (Jensen 1990). Aggregations of these small crabs are found in virtually all areas of appropriate habitat, ranging roughly from

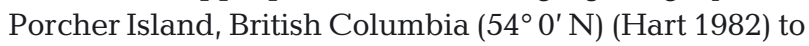
Morro Bay, California (3520' N) (author's pers. obs.).

Petrolisthes cinctipes are gregarious, and juveniles recruit beneath live conspecific adults (Jensen 1991). Adults appear to compete for access to high quality feeding spots characterized by high flow rates (Jensen 1990), and individual growth rates decline with increasing conspecific density in both the lab and the field (Donahue 2004). Petrolisthes is gonochoric, and females brood their eggs until they hatch (Nyblade 1987). Timing of reproduction varies with latitude, but in northern California females typically produce broods from February through mid-April (Donahue 2004). However, brooding females can occasionally be found at low frequency as late as September (author's pers. obs.). Although the exact mechanism of copulation in $P$. cinctipes remains unknown, mating occurs in the hard-shelled state, and large males defend territories in an attempt to monopolize access to females (Molenock 1974, 1976). Newly extruded broods may contain up to ca. 1300 embryos, each roughly $0.1 \mathrm{mg}$ in dry weight and $800 \mu \mathrm{m}$ in diameter (Donahue 2004).

Brooding makes it possible to collect a dam and all her offspring simultaneously in the field. This allows the use of molecular genetic tools to examine patterns of inheritance, and make inferences about mating behavior of these animals in the field, without the necessity of labor-intensive lab crosses.

DNA extraction. Live Petrolisthes cinctipes were harassed in order to stimulate autotomy of a cheliped, which they do readily. After dissecting $\sim 5 \mathrm{mg}$ of muscle tissue from the limb for DNA extraction, each cheliped was placed into a uniquely numbered vial filled with $95 \%$ ethanol, and stored at $-30^{\circ} \mathrm{C}$ as a backup. DNA was then extracted from the dissected muscle tissue using the PureGene kit (Gentra Systems), following their marine invertebrate extraction protocol (\#00690).

PCR amplification and electrophoresis. Primers for the microsatellite loci used in this study were isolated following the 'Microsatellites for Ecologists' protocol (Toonen 1997). Details of the isolation and characterization of the primers ( $P_{C} 156$ s and $\left.P_{C} 170 s\right)$ used to amplify microsatellite loci used in this study are described in detail elsewhere (Toonen 2001). The forward (F) and reverse (R) primer sequences for each locus used in this study are: Pc156sF (5'-TTGGCTTTGAAGACCCTGTGG-3') and Pc156sR (5'-CGGGGGATCATTGCTTTGTC-3'), Pc170sF (5'-TGGCCGTTGCTGTTGTTGTC-3') and Pc170sR (5'-GGCACCAGTCATTCCCAGTTG-3').

PCR reaction mixes contained Perkin Elmer $10 \times$ Buffer II at $1 \times$ concentration, $2.5 \mathrm{mM} \mathrm{MgCl}_{2}, 0.1 \mathrm{mM}$ each of deoxynucleoside-triphosphate (dNTPs), $1 \times$ bovine serum albumin (BSA at $1 \mathrm{mg} \mathrm{ml}^{-1}$ ), $0.5 \mathrm{mM}$ of each the forward and reverse primer, $0.2 \mathrm{U}$ Taq polymerase, and 1 to $50 \mathrm{ng}$ of template DNA adjusted to a final volume of $20 \mu \mathrm{l}$. PCR amplifications were performed using a touchdown PCR protocol on a Perkin Elmer 9700 thermocycler as follows: $94^{\circ} \mathrm{C}$ for 5 min; 2 cycles of: $94^{\circ} \mathrm{C}$ for $30 \mathrm{~s}, 68^{\circ} \mathrm{C}$ for $30 \mathrm{~s}, 72^{\circ} \mathrm{C}$ for $30 \mathrm{~s} ; 2$ cycles of: $94^{\circ} \mathrm{C}$ for $30 \mathrm{~s}, 65^{\circ} \mathrm{C}$ for $30 \mathrm{~s}, 72^{\circ} \mathrm{C}$ for $30 \mathrm{~s} ; 2$ cycles of: $94^{\circ} \mathrm{C}$ for $30 \mathrm{~s}, 63^{\circ} \mathrm{C}$ for $30 \mathrm{~s}, 72^{\circ} \mathrm{C}$ for $30 \mathrm{~s} ; 24$ cycles of: $94^{\circ} \mathrm{C}$ for $15 \mathrm{~s}, 60^{\circ} \mathrm{C}$ for $15 \mathrm{~s}, 72^{\circ} \mathrm{C}$ for $15 \mathrm{~s}$; and a final extension of $72^{\circ} \mathrm{C}$ for $20 \mathrm{~min}$.

Amplified PCR products were electrophoresed on an Applied Biosystems ABI 377 XL automated sequencer and scored using the STRand software package (Hughes 1998), as outlined in Toonen \& Hughes (2001, 2003). Summary statistics were calculated with the Arlequin population genetics data analysis program, version 2.000 (Schneider et al. 2000).

Inheritance and paternity of brooded larvae. To test for Mendelian segregation, loci were scored in 12 offspring from each of 10 brooding females provided by S. Morgan and M. Donahue from the Bodega Bay Marine Lab, California. A chela was removed from each female and muscle tissue was dissected for DNA extraction as outlined above. Offspring were selected haphazardly from a single sample of brooded embryos plucked from the pleopods of the female. Individual embryos were then extracted using the Nucleon PhytoPure plant DNA extraction kit (Amersham Biosciences), with the exception that embryos were not ground under liquid nitrogen as recommended for plant tissue. Instead, embryos were individually placed whole into extraction buffer, where each was crushed with a sterile plastic pestle (USA Scientific). 
By genotyping the mother and her brooded offspring for these 2 highly polymorphic loci, I can infer the minimum number of males with which a female must have mated. Although the genotypes of the sires for each brood are unknown in these field-collected animals, I take the conservative approach and assume that every female mated with only heterozygous males. Given this assumption, the minimum number of mates required to generate the allelic distributions detected in each family is estimated by one-half the number of non-maternal alleles. For cases in which there were an odd number of non-maternal alleles detected among the brooded offspring, estimates of the minimum number of males required were rounded up. For example, if 3 non-maternal alleles are detected, the minimum estimated number of mates must be rounded up from 1.5 to 2 males.

Given that loci $P_{C} 156 s$ and $P_{C} 170$ s have 34 and 47 alleles, respectively, and heterozygosities of 0.70 and 0.83, respectively (Toonen 2001), I have high exclusion probabilities even with only 2 loci included in these analyses. With this degree of polymorphism, the prospect of 2 individuals sharing a particular allelic combination by chance is on the order of $10^{-4}$ (Avise 1994). However, although detection of non-maternal alleles can exclude a single male as the father of an entire brood, it cannot provide an accurate estimate of the frequency of multiple matings in natural populations. Because not all males in the population are in fact heterozygous for alleles other than those carried by the mother, any estimate based solely on the number of non-maternal alleles detected will be an underestimate of the true frequency of multiple matings in the field (Neff et al. 2002). The Bayesian approach of Neff et al. (2002) takes the allele frequency distribution of the population into consideration when calculating the most likely frequency of multiple mating events in that population, and also gives a confidence interval on that estimate.

Therefore, I used the $\mathrm{F}(\mathrm{mm})$ computer program of Neff et al. (2002) to calculate the average frequency, and the $95 \%$ confidence intervals, of multiple mating in this population. To render a more conservative estimate of the frequency of multiple matings in the $\mathrm{F}(\mathrm{mm})$ analysis, I included only that subset of alleles found in a sample of 80 individuals from Bodega Bay at $>1 \%$ frequency. There were no alleles detected in the mothers or their offspring that were not among this subset of the total allelic diversity at the 2 loci. Using only these data, there were 16 alleles at locus PC156s, and 17 at locus PC170s. Even with only 2 microsatellite loci that have this degree of polymorphism, exclusion probabilities are on the order of $10^{-3}$, and my estimate of multiple paternity is therefore likely to be an underestimate. Furthermore, I have sufficient power by genotyping 12 offspring from each of 10 females to reliably detect $>95 \%$ of multiple matings (Avise 1994, Neff \& Pitcher 2002, Neff et al. 2002). Thus, the frequency of multiple mating estimated by these 2 loci is conservative relative to the true population value (Neff \& Pitcher 2002).

\section{RESULTS}

There was no evidence of deviation from expected Mendelian ratios of codominant autosomal loci for either locus Pc170s or Pc156s. Neither locus showed a significant deviation from Hardy-Weinberg expectations ( $p>0.05)$, and no null alleles were detected in this study. All genotyped offspring contained at least 1 of the maternal alleles (Table 1), and across the 10 families examined, the ratio of maternal alleles detected among the offspring did not differ from 1:1 for either PC170s (df $=1, \chi^{2}=0.405, \mathrm{p}>0.05$ ) or PC156s $\left(\mathrm{df}=1, \chi^{2}=0.348, \mathrm{p}>0.05\right)$.

Single paternity of broods can be rejected for 8 of the 10 families examined in this study because there are more than 2 non-maternal alleles observed among the offspring (Table 1). Given that the minimum number of mates will underestimate the contribution of any homozygous males or those that share an allele with the mother, this estimate of the minimum number of mates is conservative. Furthermore, each female carried hundreds of brooded embryos of which only 12 from a single small area of the brood were genotyped. Regardless, I detected as many as 5 non-maternal alleles (requiring a minimum of 3 males) among this small proportion of genotyped offspring (Table 1). Using the F(mm) software package of Neff et al. (2002), I found that the maximum likelihood estimate for the frequency of multiple mating in this population was $92.5 \%$. The $95 \%$ confidence interval for this estimate ranges from 71 to $100 \%$ of females in the population that produce broods of mixed paternity.

\section{DISCUSSION}

Based on the allele frequency distribution among offspring, both loci used in this study appear to be codominant autosomal loci that segregate independently. Using these loci to genotype the offspring of brooding dams also provided novel information about the mating system of Petrolisthes cinctipes. By counting the number of non-maternal alleles detected at each locus among the offspring, I estimate that the minimum number of males that fertilize broods of individual females ranges from 1 to 3 (Table 1). In 8 of 10 females tested, single paternity of their broods could 
Table 1. Petrolisthes cinctipes. Summary of allelic inheritance data from a sample of 12 brooded offspring from each of 10 gravid females of the anomuran crab. In each case, mother refers to the gravid female from which brooded embryos (offspring) were collected. Detected alleles are identified by the length of the amplification product (in bp). The minimum number of males with which each female must have mated to generate the observed allelic distribution among the offspring is estimated by $1 / 2$ the number of non-maternal alleles observed at either locus (see subsection 'Inheritance and paternity of brooded larvae')

\begin{tabular}{|c|c|c|c|c|c|}
\hline \multirow[t]{2}{*}{ Family } & \multicolumn{2}{|c|}{ Locus PC156s } & \multicolumn{2}{|c|}{ Locus $P_{C} 170 \mathrm{~s}$} & \multirow{2}{*}{$\begin{array}{l}\text { Minimum no. } \\
\text { of males }\end{array}$} \\
\hline & Mother & Offspring & Mother & Offspring & \\
\hline \multirow[t]{2}{*}{1} & 76 & $76,78,82,86,100,120$ & 126 & $126,128,134$ & 2 \\
\hline & 120 & & 128 & & \\
\hline \multirow[t]{2}{*}{2} & 76 & 76,120 & 116 & $90,116,126,128,142$ & 2 \\
\hline & 120 & & 126 & & \\
\hline \multirow[t]{2}{*}{3} & 76 & $76,78,120$ & 126 & $90,100,116,128,142$ & 2 \\
\hline & 120 & & 128 & & \\
\hline \multirow[t]{2}{*}{4} & 76 & $76,78,90,94,120$ & 126 & $96,126,128,134,142,144$ & 2 \\
\hline & 120 & & 142 & & \\
\hline \multirow[t]{2}{*}{5} & 76 & $76,84,86,98,106,120$ & 126 & $90,112,126,128,140,142,200$ & 3 \\
\hline & 120 & & 128 & & \\
\hline \multirow[t]{2}{*}{6} & 76 & $76,78,82,108,120$ & 116 & $116,124,128,140,142$ & 2 \\
\hline & 120 & & 128 & & \\
\hline \multirow[t]{2}{*}{7} & 76 & $76,78,88,120$ & 126 & $116,126,128,142$ & 1 \\
\hline & 120 & & 128 & & \\
\hline \multirow[t]{2}{*}{8} & 76 & $76,94,98,106,120$ & 128 & $98,126,128,140,142$ & 2 \\
\hline & 120 & & 128 & & \\
\hline \multirow[t]{2}{*}{9} & 76 & $76,78,92$ & 126 & $92,126,128$ & 1 \\
\hline & 76 & & 128 & & \\
\hline \multirow[t]{2}{*}{10} & 76 & $76,78,86,94,120$ & 126 & $126,128,132,134$ & 2 \\
\hline & 94 & & 128 & & \\
\hline
\end{tabular}

be unambiguously rejected (Table 1). Furthermore, using the Bayesian approach of Neff et al. (2002), I estimate that roughly $92.5 \%$ of females in the Bodega Bay population were carrying broods fathered by more than a single male.

Multiple matings have been observed in a variety of crab species, but studies of paternity in crabs remain rare (reviewed by Urbani et al. 1998). Proposed benefits of multiple matings include: (1) prolonged guarding of vulnerable females by their mate (e.g. Jensen et al. 1996); (2) ensuring fertilization because (a) some males may be sterile, (b) males invest less sperm than females require when they partition their ejaculate among multiple females, or (c) there is a reduction of active sperm in storage organs due to passive loss or sperm mortality over time (reviewed by Jennions \& Petrie 2000); (3) selection of more genetically compatible sperm and avoidance of intra-genomic conflict among offspring (reviewed by Zeh \& Zeh 1996); (4) elevating offspring fitness by increasing the number of potential sires that compete (e.g. Kellogg et al. 1995); and (5) increasing the genetic diversity among offspring as a form of bet-hedging (reviewed by Schneider \& Elgar 1998, Jennions \& Petrie 2000). However, despite the range of potential advantages for multiple mating, studies that document the genetic composition of broods remain scarce. Those studies that have been done to date focus primarily on brachyuran crabs; despite multiple copulations and the presence of sperm storage organs in those few species studied to date, multiple paternity appears rare (e.g. Diesel 1989, 1991, Koga et al. 1993, Jensen et al. 1996, Urbani et al. 1998).

In contrast, the data presented here indicate that the majority of females of Petrolisthes cinctipes in Bodega Bay carried broods of multiple paternity (Table 1). Molenock $(1974,1976)$ reported that dominant male $P$. cinctipes maintain territories ca. $10 \mathrm{~cm}$ in diameter from which they exclude other males. However, Molenock also noted seeing several small males successfully mate within the territory of a larger male. The results of this study suggest that such mating may be a frequent occurrence, and that large males are rarely, if ever, successful in monopolizing access to receptive females; multiple paternity of broods seems widespread in this species. Even when only 12 of the hundreds of offspring carried per brood were sampled, 8 of 10 females were shown to carry broods with more than 2 unique paternal alleles. These data suggest that multiple paternity of broods is the rule rather than the exception for the porcelain shore crab $P$. cinctipes. 
Acknowledgements. I wish to thank my dissertation committee, R. Grosberg, R. Burton, and M. Stanton, my fellow graduate students, the 'Gros-Docs' (especially M. Hart, A. Wilson, and J. Wares) and DBS Core Sequencing Facility at UC Davis for their support and assistance throughout this project. Thanks to S. Morgan and M. Donahue for providing the gravid females that I used in this study. I also thank M. Cahill, T. Mai, C. Fong and especially A. Chang for their assistance in the laboratory with this research. The comments of G. Jensen and the anonymous reviewers greatly improved this manuscript. Finally, I wish to thank B. Neff for his assistance in getting $\mathrm{F}(\mathrm{mm})$ to run with my data. This research was funded by a grant from the National Sea Grant College Program, National Oceanic and Atmospheric Administration, US Department of Commerce, under grant number NA06RG0142, project number R/F-177 through the California Sea Grant College System. The views expressed herein are those of the author and do not necessarily reflect the views of NOAA or any of its sub-agencies. The US Government is authorized to reproduce and distribute for governmental purposes. This is contribution \#1174 from the Hawaii Institute of Marine Biology, and SOEST \#6320.

\section{LITERATURE CITED}

Andersson M (1994) Sexual selection. Princeton University Press, Princeton, NJ

Avise JC (1994) Molecular markers, natural history and evolution. Chapman \& Hall, New York

Birkhead TR (2000) Promiscuity: an evolutionary history of sperm competition. Harvard University Press, Boston, MA

Diesel R (1989) Structure and function of the reproductive system of the symbiotic spider crab Inachus phalangium (Decapoda, Majidae): observations on sperm transfer, sperm storage and spawning. J Crustac Biol 9:266-277

Diesel R (1991) Sperm competition and the evolution of mating behavior in Brachyura, with special reference to spider crabs (Decapoda: Majidae). In: Bauer RG, Martin JW (eds) Crustacean sexual biology. Columbia University Press, New York, p 145-163

Donahue MJ (2004) Size-dependent competition in a gregarious porcelain crab Petrolisthes cinctipes (Anomura: Porcellanidae). Mar Ecol Prog Ser 267:219-231

Hart JFL (1982) Crabs and their relatives of British Columbia, Handbook 40, Vol. British Columbia Provincial Museum, Victoria, BC

Hosken DJ (1999) Sperm displacement in yellow dung flies: a role for females. Trends Ecol Evol 14:251-252

Hughes S (1998) STRand nucleic acid analysis software. Regents of the University of California, Davis, CA

Jennions MD, Petrie M (2000) Why do females mate multiply? A review of the genetic benefits. Biol Rev Camb Phil Soc 75:21-64

Jensen GC (1990) Intertidal zonation of porcelain crabs: resource partitioning and the role of selective settlement. $\mathrm{PhD}$ dissertation, University of Washington, Seattle, WA

Jensen GC (1991) Competence, settling behavior, and postsettlement aggregation by porcelain crab megalopae (Anomura, Porcellanidae). J Exp Mar Biol Ecol 153:49-61

Jensen GC, Armstrong DA (1991) Intertidal zonation among congeners - factors regulating distribution of porcelain crabs Petrolisthes spp. (Anomura, Porcellanidae). Mar Ecol Prog Ser 73:47-60

Jensen PC, Orensanz JM, Armstrong DA (1996) Structure of the female reproductive tract in the Dungeness crab (Cancer magister) and implications for the mating system. Biol Bull (Woods Hole) 190:336-349

Editorial responsibility: Don Levitan (Contributing Editor),

Tallahassee, Florida, USA
Kellogg KA, Merkert JA, Stauffer JR, Kocher TD (1995) Microsatellite variation demonstrates multiple paternity in lekking cichlid fishes from Lake Malawi, Africa. Proc R Soc Biol Sci Ser B 260:79-84

Koga T, Henmi Y, Murai M (1993) Sperm competition and the assurance of underground copulation in the sand-bubbler crab Scopimera globosa (Brachyura: Ocypodidae). J Crustac Biol 13:134-137

Molenock J (1974) Evolutionary aspects of communication in the courtship behaviour of four species of anomuran crabs (Petrolisthes). Behaviour 53:1-30

Molenock J (1976) Agonistic inetractions of the crab Petrolisthes (Crustacea, Anomura). Zeitschrift fuer Tierpsychologie. J Comp Ethol 41:277-294

Neff BD, Pitcher TE (2002) Assessing the statistical power of genetic analyses to detect multiple mating in fishes. J Fish Biol 61:739-750

Neff BD, Pitcher TE, Repka J (2002) A Bayesian model for assessing the frequency of multiple mating in nature. J Hered 93:406-414

Nyblade CF (1987) Phylum or Subphylum Crustacea, Class Malacostraca, Order Decapoda, Anomura. In: Strathmann MF (ed) Reproduction and development of marine invertebrates of the Northern Pacific Coast: data and methods for the study of eggs, embryos and larvae. University of Washington Press, Seattle, WA, p 441-450

Pizzari T, Birkhead TR (2002) The sexually-selected sperm hypothesis: sex-biased inheritance and sexual antagonism. Biol Rev 77:183-209

Powell GC, Nickerson RB (1965) Reproduction of king crabs, Paralithodes camtschatica (Tilesius). J Fish Res Board Can 22:101-111

Reynolds JD (1996) Animal breeding systems. Trends Ecol Evol 11:68-72

Schneider JM, Elgar MA (1998) Spiders hedge genetic bets. Trends Ecol Evol 13:218-219

Schneider S, Roessli D, Excoffier L (2000) Arlequin: a software for population genetics data analysis. Genetics and Biometry Laboratory, University of Geneva

Toonen RJ (1997) Microsatellites for ecologists: non-radioactive isolation and amplification protocols for microsatellite markers. University of California, Davis, CA

Toonen RJ (2001) Genetic analysis of recruitment and dispersal patterns in the porcelain shore crab, Petrolisthes cinctipes. PhD Dissertation, University of California, Davis, CA

Toonen RJ, Hughes S (2001) Increased throughput for fragment analysis on an ABI Prism(R) 377 automated sequencer using a membrane comb and STRand software. Biotechniques 31:1320-1324

Toonen RJ, Hughes S (2003) Increased throughput for fragment analysis on an ABI 377 automated sequencer using a 100-lane RapidLoad membrane comb and STRand software, and update. In: Brown SM (ed) BioComputing: computer tools for biologists, Vol Section IV, CH 46. Eaton Publishing, Westborough, MA

Urbani N, Sainte-Marie B, Sevigny JM, Zadworny D, Kuhnlein U (1998) Sperm competition and paternity assurance during the first breeding period of female snow crab (Chionoecetes opilio) (Brachyura: Majidae). Can J Fish Aquat Sci 55:1104-1113

Wicksten MK (1973) Feeding in the porcelain crab, Petrolisthes cinctipes (Randall) (Anomura: Porcellanidae). Bull South Calif Acad Sci 72:161-163

Zeh JA, Zeh DW (1996) The evolution of polyandry. 1. Intragenomic conflict and genetic incompatability. Proc R Soc Lond Ser B Biol Sci 263:1711-1717

Submitted: September 9, 2003; Accepted: February 10, 2004 Proofs received from author(s): April 2, 2004 